\title{
Carbon sequestration potential of agroforestry systems in the Indian arid zone
}

\author{
S. P. S. Tanwar*, Praveen Kumar, Archana Verma, R. K. Bhatt, Akath Singh, \\ Kanhaiya Lal, M. Patidar and B. K. Mathur
}

ICAR-Central Arid Zone Research Institute, Jodhpur 342 003, India

Carbon sequestration potential of eight recommended land-use systems of arid western Rajasthan was compared. Biomass $C$ stock was maximum in farm forestry of Acacia tortilis (31.4 $\mathrm{Mg} \mathrm{C} \mathrm{ha}^{-1}$ ) followed by Prosopis cineraria and Hardwickia binata based silvoarable systems $\left(8.8\right.$ and $\left.10.6 \mathrm{Mg} \mathrm{Cha}^{-1}\right)$. Soil $\mathrm{C}$ stock was also maximum in farm forestry (47.6 $\mathrm{Mg} \mathrm{C} \mathrm{ha}^{-1}$ ) followed by Ziziphus based systems (32.5-33.9 $\mathrm{Mg} \mathrm{C} \mathrm{ha}^{-1}$ ). About $50-78 \%$ of additional soil $\mathrm{C}$ stock was in the form of soil inorganic carbon. The total $\mathrm{C}$ sequestered (biomass + soil) over a period of nineteen years was in the order: farm forestry $(49.80)>$ silvoarable systems $\quad(11.0-13.3)>$ hortipasture system $(8.3)>$ agri-horti $(5.5)$, silvopasture (5.4) and sole pasture (5.3) compared to $-1.0 \mathrm{Mg} \mathrm{C} \mathrm{ha}^{-1}$ in sole cropping.

Keywords: Agroforestry, arid zone, carbon sequestration, climate change mitigation.

CARBON sequestration in the biosphere has now become an important strategy to offset the effect of increasing carbon dioxide $\left(\mathrm{CO}_{2}\right)$ in the atmosphere. It may potentially reduce or offset $10-40 \%$ (i.e. $0.40-2.80 \mathrm{PG} \mathrm{C}^{\mathrm{C}}$ year $^{-1}$ ) of current total greenhouse gas (GHG) emissions ${ }^{1-4}$. In highly populated countries like India, further scope of putting more land under forests is limited. However, tree cover can be increased by growing trees/shrubs in farmlands referred to as agroforestry ${ }^{5}$. This is traditionally being followed in almost all parts of India, especially in Rajasthan, Gujarat and Maharashtra ${ }^{5,6}$. In Rajasthan, it is a tradition to protect growing trees and maintain them in agricultural fields as well as in pastures. The average carbon sequestration potential of the existing agroforestry systems of India was estimated to be $25 \mathrm{Mg} \mathrm{Cha}^{-1}$ distributed over 96 million ha area ${ }^{7}$. In a recent survey of 32 districts in 12 states, the carbon sequestration rate of these agroforestry systems on farmers' fields at the district level varied from 0.05 to $2.78 \mathrm{Mg} \mathrm{C} \mathrm{ha}^{-1}$ year $^{-1}$ which could be substantially increased through improved agroforestry systems to $0.25-76.55 \mathrm{Mg} \mathrm{C} \mathrm{ha}^{-1}$ year $^{-1}$ (ref. 6). However, the estimates of improved systems were based mostly on

*For correspondence. (e-mail: spstanwar@gmail.com) block plantations with very high densities of juvenile trees (2-10 years of age). Accurate information on spatial distribution of $\mathrm{C}$ in the soil and vegetation of mature systems with recommended tree density and management practices is important for formulation of policies and actions. This is more relevant for fragile environments like arid regions.

The arid regions by virtue of their vastness $(\sim 25 \%$ of global land area) can play a major role in climate change mitigation by sequestering $\mathrm{C}$ through afforestation on highly degraded common lands and increasing tree cover on farmlands through agroforestry. The estimated potential of $\mathrm{C}$ sequestration in desert ecosystem is 10-20 TG C year $^{-1}$ in Central Asia, 200-400 TG C year ${ }^{-1}$ in West Asia and North Africa, and $\sim 1000 \mathrm{TG} \mathrm{C}$ year $^{-1}$ in global dryland ecosystems ${ }^{3,4,8,9}$. The hot Indian arid zone constitutes about $31.7 \mathrm{~m}$ ha area in northwestern India. Traditionally, trees are an important drought-proofing component of farming systems in the arid regions and provide fodder, fuelwood, timber and other minor products even when crops fail. However, in the last 50 years, more land has been put under sole cultivation of annual crops like pearl millet and this has resulted in depletion of soil organic carbon $(\mathrm{SOC})^{10}$. In agroforestry-based alternate land-use systems (LUS), SOC was either maintained or improved. Prosopis cineraria is the most prominent tree species in farmlands and pastures of this region $\left(5-31 \text { trees ha }{ }^{-1}\right)^{11}$. To attain higher levels of sustenance and livelihood security in the otherwise harsh and unpredictable arid climate, newer agroforestry systems have also been developed involving other species like Hardwickia binata, Ziziphus mauritiana, Colophospermum mopane, etc. They have been well tested for their economic viability and treecrop/grass-animal interactions ${ }^{12-14}$. Moreover, their $\mathrm{C}$ sequestration potential in biomass and soil is less studied.

The $\mathrm{C}$ sequestration is expected to occur in biomass as well as soil. Biomass production is a function of genetic potential of species and edapho-climatic conditions of a region. While litterfall and its decomposition are two major processes accounting for soil $\mathrm{C}$ enrichment. In the arid fringes of Rajasthan, $\mathrm{C}$ enrichment in soil by trees was in the order $P$. cineraria $>$ Delbergia sisoo $>$ Acacia leucophloea $>$ Acacia nilotica ${ }^{15}$. The SOC increased significantly under Z. mauritiana in Bikaner, 
RESEARCH ARTICLES

Table 1. Physico-chemical properties of soil profile of the experimental site

\begin{tabular}{|c|c|c|c|c|c|c|}
\hline \multirow[b]{2}{*}{ Soil depth (cm) } & \multicolumn{3}{|c|}{ Soil texture (\%) } & \multirow[b]{2}{*}{$\mathrm{pH}$} & \multirow[b]{2}{*}{$\operatorname{ECe}\left(\mathrm{dS} \mathrm{m}^{-1}\right)$} & \multirow[b]{2}{*}{$\mathrm{CaCO}_{3}(\%)$} \\
\hline & Sand & Silt & Clay & & & \\
\hline $0-15$ & 83.7 & 8.4 & 7.9 & 8.2 & 0.35 & 0.09 \\
\hline $15-30$ & 81.2 & 8.7 & 10.1 & 8.3 & 0.41 & 0.14 \\
\hline $30-45$ & 78.8 & 9.1 & 12.1 & 8.2 & 0.63 & 0.26 \\
\hline $45-60$ & 74.6 & 8.8 & 16.6 & 8.1 & 0.68 & 0.31 \\
\hline $60-75$ & 74.2 & 9.3 & 16.5 & 8.3 & 0.68 & 0.35 \\
\hline $75-100$ & 74.2 & 10.1 & 15.7 & 8.3 & 0.55 & 0.47 \\
\hline
\end{tabular}

ECe, Electrical conductivity of saturation extract of soil.

Rajasthan $^{16,17}$. Ten-year-old Acacia tortilis and neembased silvopastoral systems in the arid Kachchh region sequestered $4.91-6.15 \mathrm{MgC} \mathrm{ha}^{-1}$ in biomass and improved SOC stock by $27.1-70.8 \%$ over sole pasture ${ }^{18}$. Similarly, in hot semi-arid region (Pali, Rajasthan), 30year-old, high-density $H$. binata-based silvopastoral system (666 trees $\mathrm{ha}^{-1}$ ) sequestered $31.6 \mathrm{Mg} \mathrm{C} \mathrm{ha}^{-1}$ in tree biomass and improved SOC stock by $16.6 \%$ over sole pasture $^{19}$. These estimates would have been higher if changes in soil inorganic carbon (SIC) were also considered. In fact, SIC, rather than SOC, is the dominant form of carbon in the arid and semi-arid regions ${ }^{20-22}$. To bridge these gaps in estimation, we aimed to quantify carbon sequestration in eight 19-year-old mature LUS recommended for this region with the following objectives: (i) to determine the amount of $\mathrm{C}$ annually harvested as economic product in these systems and (ii) to quantify the amount of $\mathrm{C}$ sequestered in biomass and soil, and its vertical distribution in soil profile.

\section{Materials and method}

\section{Site description}

The present study was carried out in an established integrated farming system (IFS) experiment at the ICARCentral Arid Zone Research Institute (ICAR-CAZRI), Jodhpur, Rajasthan, India $\left(26^{\circ} 14^{\prime} \mathrm{N}\right.$ and $72^{\circ} 59^{\prime} \mathrm{E}$ at $216 \mathrm{~m}$ amsl). Climate of the region is arid with average annual rainfall of $360 \mathrm{~mm}$ occurring mainly in 6-8 rainfall events. It experiences very high temperature during summers touching a maximum of $48^{\circ} \mathrm{C}$, short, cool and dry winters $\left(4.1^{\circ}-14^{\circ} \mathrm{C}\right)$, high evaporation (3.5$13.5 \mathrm{~mm} \mathrm{day}^{-1}$ ) and low humidity. The soil was classified as coarse loamy Typic haplocambids. Table 1 presents some of the characteristics of soil profile.

\section{Experimental setup and field operations}

Eight different LUS maintained under a 19-year-old IFS experiment ( 7 ha area) were chosen for this study. These were: (i) arable (C)-crops alone, (ii) silvoarable
$(\mathrm{P}+\mathrm{C})-P$. cineraria + crops, (iii) silvoarable $(\mathrm{H}+\mathrm{C})-$ H. binata + crops, (iv) agri-horti $(\mathrm{Z}+\mathrm{C})-\mathrm{Z}$. mauritiana + grass, (v) sole pasture (G) - Cenchrus ciliaris, (vi) hortipasture $(\mathrm{Z}+\mathrm{G})-\mathrm{Z}$. mauritiana + grass, (vii) silvopasture $(\mathrm{C}+\mathrm{G})-C$. mopane + grass, and (viii) farm forestry $(\mathrm{T})$ - Acacia tortilis. In each LUS, five subplots of $50 \mathrm{~m} \times 30 \mathrm{~m}$ were taken as replicates. In crop-based systems, i.e. arable, silvoarable and agri-horti, four rainy season crops, i.e. pearl millet (Pennisetum glaucum), clusterbean (Cyamopsis tetragonoloba), green gram (Phaseolus radiatus) and dew gram (Phaseolus aconitifolia) were grown in ratio $2: 1: 1: 1$, following a pearl millet-legume rotation. Table 2 summarized management practices that have a major impact on carbon accumulation.

\section{Variables evaluated}

Net annual harvested $C(N H C)$ : This includes sum total of carbon in the annual harvested biomass, i.e. crop biomass (seed and forage), fruits (Z. mauritiana), leaves as lopping, fuel wood and grass grazed/cut (estimated from paddocks of $5 \mathrm{~m} \times 5 \mathrm{~m}$ ). This was calculated by multiplying the biomass (commodity-wise) harvested annually with its carbon content and averaged over five years (2012-2016).

Growth of trees and Biomass $C$ stock: Height, diameter at breast height (DBH) and canopy spread were recorded for all trees in each replicate. Individual tree biomass (dry) was estimated using locally developed allometric equations for $H$. binata (equation developed by felling 20 trees from the experiment with $r^{2}$ value $\left.=0.96\right)$ and $A$. tortilis $^{23}$; and for rest of the species, the model developed by Chave et ll $^{24}$ for dry forests was used (Table 3). Specific gravity $(b)$ was estimated using core method ${ }^{25}$. The samples taken for estimating specific gravity were then used for estimating $\mathrm{C}$ in individual species using Euro vector CNHS analyser. The biomass harvested during thinning of tree stand (in farm forestry) and while rejuvenating the trees (in horti-pasture) was also added while calculating biomass $\mathrm{C}$ stock. Since grass cover was 
RESEARCH ARTICLES

Table 2. Management practices followed in different land-use systems (LUS)

\begin{tabular}{|c|c|c|c|}
\hline Activity & $\begin{array}{c}\text { Crop-based systems } \\
(\mathrm{AR}, \mathrm{P}+\mathrm{C}, \mathrm{H}+\mathrm{C}, \mathrm{Z}+\mathrm{C})\end{array}$ & $\begin{array}{l}\text { Grass-based systems } \\
(\mathrm{G}, \mathrm{Z}+\mathrm{G}, \mathrm{M}+\mathrm{G})\end{array}$ & Farm forestry $(\mathrm{T})$ \\
\hline Ploughing & $\begin{array}{l}\text { Summer ploughing (once in three years), } \\
\text { disc harrow (10-12.5 cm depth) } \\
\text { followed by one run of cultivator } \\
\text { and planking. }\end{array}$ & $\begin{array}{l}\text { Inter-cultivation after first } \\
\text { effective rainfall with tractor- } \\
\text { drawn implements } \\
\text { (tyne width } 60 \mathrm{~cm} \text { ). }\end{array}$ & No tillage \\
\hline & $\begin{array}{l}\text { Greengram and clusterbean }-10 \mathrm{~kg} \mathrm{~N} \\
\text { and } 30 \mathrm{~kg} \mathrm{P}_{2} \mathrm{O}_{5} \mathrm{ha}^{-1} \text { at sowing. } \\
\text { Dewgram }-10 \mathrm{~kg} \mathrm{~N} \text { and } 20 \mathrm{P}_{2} \mathrm{O}_{5} \mathrm{ha}^{-1} \\
\text { at sowing. }\end{array}$ & & \\
\hline Tree management & $\begin{array}{l}\text { Pruning carried out every year after the } \\
\text { fifth year of plantation: } \\
\text { Prosopis cineraria - November to February } \\
\text { Hardwickia binata - January-March } \\
\text { and September-November } \\
\text { Ziziphus mauritiana - May }\end{array}$ & $\begin{array}{l}\text { Colophospermum mopane- } \\
\text { pruning during November-February } \\
\mathrm{Z}+\mathrm{G} \text { system - Trees of } \\
\text { Ziziphus rotundifolia were } \\
\text { rejuvenated during the } 11 \text { th } \\
\text { year by heading back and then grafted } \\
\text { with } Z \text {. mauritiana yielding } 3.6 \text { tonnes } \\
\text { of dry wood. }\end{array}$ & $\begin{array}{l}\text { To manage the canopy, } \\
150 \text { trees of Acacia tortilis } \\
\text { were harvested in the } 16 \text { th } \\
\text { year of plantation yielding } \\
16.3 \text { tonnes of dry wood. }\end{array}$ \\
\hline Grazing management & $\begin{array}{l}\text { Controlled grazing of small ruminants } \\
\text { during lean period }\end{array}$ & $\begin{array}{l}\text { Controlled grazing@1.5 adult cattle } \\
\quad \text { units ha }{ }^{-1}\end{array}$ & $\begin{array}{l}\text { Controlled grazing of small } \\
\text { ruminants throughout the year. }\end{array}$ \\
\hline
\end{tabular}

Table 3. Allometric equations used for estimating tree biomass and biomass carbon

\begin{tabular}{|c|c|c|c|}
\hline Component & Tree species & Equation & Abbreviations/values assigned \\
\hline Aboveground biomass (AGB) & $\begin{array}{l}\text { H. binata } \\
\text { A. } \text { tortilis }^{14} \\
\text { P. } \text { cineraria, Ziziphus sp., }_{\text {C. } \text { mopane }^{15}}\end{array}$ & $\begin{array}{l}0.0700 \times D^{2.5907} \\
(\mathrm{~V})=-0.09415 \\
\quad+0.0253594 \times \mathrm{D} \\
\mathrm{AGB}=V \times \mathrm{P} \\
0.112 \times\left(b \mathrm{D}^{2} H\right)^{0.916}\end{array}$ & $\begin{array}{l}D \text { is the diameter at breast height } \\
V \text { is the wood volume, } \\
D \text { is the specific gravity of wood } \\
D=0.93,0.90,0.97 \text { and } 0.89 \mathrm{~g} \mathrm{~cm}^{-3} \text { respectively, for } \\
H . \text { binata, P. cineraria, Ziziphus sp. and C. mopane } \\
H \text { is the height of tree }\end{array}$ \\
\hline $\begin{array}{l}\text { Belowground biomass (BGB) } \\
\text { Total biomass (TB) }\end{array}$ & All species ${ }^{38}$ & $\begin{array}{l}0.26 \times \mathrm{AGB} \\
\mathrm{AGB}+\mathrm{BGB}\end{array}$ & \\
\hline Total tree biomass carbon & & $\mathrm{TB} \times \mathrm{C}$ & $\begin{array}{l}\mathrm{C} \text { is the carbon content in wood biomass i.e. } \\
0.464,0.472,0.531,0.470 \text { and } 0.467 \text { for } \\
P . \text { cineraria, Zizipus sp., C. mopane, H. binata } \\
\text { and } A \text {. tortilis, respectively. }\end{array}$ \\
\hline
\end{tabular}

permanent in pasture treatments, we assumed the grass biomass left in stubbles (3-6 cm height) after grazing to be sequestered carbon ${ }^{26}$. To estimate this, three quadrats $(1.2 \mathrm{~m} \times 1.2 \mathrm{~m})$ in each subplot were sampled randomly in December after completion of grazing by the animals. The stumps were dug along with their roots, cleaned, dried and weighed. This was then multiplied by $\mathrm{C}$ content and averaged over seven years (2012-2018). Biomass C stocks (tree + grass) were then presented as $\mathrm{Mg} \mathrm{C} \mathrm{ha}^{-1}$.

Soil $C$ concentration and stock: Soil samples were collected at depths of $0-15,15-30,30-45,45-60$ and 60
$100 \mathrm{~cm}$ in the 19th year of establishment. In tree-based systems, samples were collected at regular intervals of $2 \mathrm{~m}$ from the tree trunk and single composite sample for each sub plot per depth was prepared. In arable and sole pasture systems, four samples were taken at random from each sub plot avoiding borders and composited into a single sample for each depth. Bulk density was determined only in one profile of each subplot by core samples. The samples were oven-dried at $55^{\circ} \mathrm{C}$ for $72 \mathrm{~h}$, ground and passed through $2 \mathrm{~mm}$ sieve. Total soil $\mathrm{C}$ was measured using Euro vector CHNS analyser. SOC concentration was estimated by Walkley and Black method ${ }^{27}$. The SIC 
was then calculated as the difference between total soil $\mathrm{C}$ and SOC. Depth-wise distribution of SOC and SIC concentration was presented as $\mathrm{g} \mathrm{kg}^{-1}$ soil. While SOC, SIC and total soil $\mathrm{C}$ stock were calculated in $\mathrm{Mg} \mathrm{C} \mathrm{ha}^{-1}$.

Total $C$ stock and sequestration rate: The biomass $\mathrm{C}$ and total soil $\mathrm{C}$ stock were added to calculate total $\mathrm{C}$ stock. The initial soil $\mathrm{C}$ stock at the time of establishment of the experiment was subtracted from it to get total $\mathrm{C}$ sequestered over a period of 19 years. The initial soil $\mathrm{C}$ stock values were $29.2 \mathrm{MgC} \mathrm{ha}^{-1}$ in $\mathrm{G}$ and $\mathrm{T}, 29.3 \mathrm{Mg} \mathrm{C} \mathrm{ha}^{-1}$ in $\mathrm{AR}, \mathrm{P}+\mathrm{C}$ and $\mathrm{Z}+\mathrm{C}$, and $29.5 \mathrm{Mg} \mathrm{Cha}^{-1}$ in $\mathrm{H}+\mathrm{C}$, $\mathrm{Z}+\mathrm{G}, \mathrm{M}+\mathrm{G}$ systems respectively. The total $\mathrm{C}$ sequestered was then divided by the age of the systems (i.e. 19 years) to arrive at the $\mathrm{C}$ sequestration rate $\left(\mathrm{Mg} \mathrm{C} \mathrm{ha}{ }^{-1}\right.$ year $^{-1}$ ).

\section{Statistical analysis}

Data of soil C concentration (both SOC and SIC) were subjected to statistical analysis using two-way analysis of variance (ANOVA) by taking LUS as the main plot and soil depth as the subplot. Other parameters were tested using one-way ANOVA. The assumptions of ANOVA were checked by visually examining the residuals against predicted values and using the Shapiro-Wilk normality test. If null hypothesis was rejected (at $P<0.05$ ), the least significant difference (LSD) between two means was calculated using Fisher test of means. Linear regression analysis was carried out to evaluate the relationship between SOC and SIC. All the analysis were carried out using XLSTAT software.

\section{Results and discussion}

\section{Net annual harvested C (NHC)}

NHC represents $\mathrm{C}$ in the total economic biomass that was harvested annually in different LUS. Higher biomass productivity of crops than grasses resulted in the removal of higher $\mathrm{C}$ in crop-based systems (AR, $\mathrm{P}+\mathrm{C}, \mathrm{H}+\mathrm{C}$, $Z+C)$ than grass-based systems $(G, Z+G, M+G$; Figure 1). Association of trees either with crops or pastures had significantly increased NHC over sole systems. Significantly highest NHC was recorded under $H$. binatabased silvoarable system (4.92 $\mathrm{Mg} \mathrm{ha}^{-1}$ year $^{-1}$ ) followed by Ziziphus-based agri-horti system (3.93 $\mathrm{Mg} \mathrm{ha}^{-1}$ year ${ }^{-1}$ ). This was mainly due to higher fuelwood and top feed (tree leaves) harvested from these species. The contribution of tree component as fuelwood and top feed in total NHC was $75.6 \%, 70.0 \%$ and $47.6 \%$ in crop-based systems $(\mathrm{H}+\mathrm{C}, \mathrm{Z}+\mathrm{C}, \mathrm{P}+\mathrm{C}$ respectively), and $68.7 \%$ and $69.0 \%$ in pasture-based systems $(M+G$ and $Z+G$, respectively). Although NHC is not considered to be the sequestered $\mathrm{C}$ as it is not locked into the biomass for a considerable period, it is an indication of the indirect role of these LUS in mitigating climate change by fulfiling the forage and fuelwood requirements from farm itself, which would otherwise be gathered from already overexploited existing vegetation cover in common lands in this region.

\section{Accumulated biomass C stock}

The growth-attributing characters, i.e. $\mathrm{DBH}$, height and canopy spread and therefore the individual tree biomass $\left(421.30 \pm 72.86 \mathrm{~kg}\right.$ tree $^{-1}$; Table 4$)$ were highest in $P$. cineraria. The biomass of individual trees of $H$. binata and A. tortilis was $36.8 \%$ and $74.7 \%$ respectively, to that of $P$. cineraria. When calculated on per hectare basis, the biomass $\mathrm{C}$ stock was 1.2 and 3.56 times higher in $\mathrm{H}+\mathrm{C}$ and $\mathrm{T}$ respectively, over the $\mathrm{P}+\mathrm{C}$ system $\left(8.80 \mathrm{Mg} \mathrm{C} \mathrm{ha}^{-1}\right)$. This was mainly due to higher tree density of these systems over $\mathrm{P}+\mathrm{C}$. The initial tree density of $A$. tortilis was 5.9 times higher (266 trees $\mathrm{ha}^{-1}$ ) over $P$. cineraria (45 trees $\mathrm{ha}^{-1}$ ). Of this, about $16.3 \mathrm{Mg} \mathrm{Cha}^{-1}$ wood obtained by harvesting 150 trees during the 14th year of establishment for canopy management was also added to the estimated biomass of the present tree stand (116 trees $\mathrm{ha}^{-1}$ ) in the $\mathrm{T}$ system. Besides, a considerable amount of $\mathrm{C}$ assimilated was removed every year as top feed and fuelwood during lopping of $P$. cineraria and $H$. binata, causing less accumulation of $\mathrm{C}$ in these systems. Through different studies it can be inferred that A. tortilis has higher survival and growth rate in comparison to other species under study and hence found suitable for sanddune stabilization and rehabilitation of degraded lands in arid regions ${ }^{28,29}$. Least biomass accumulation was recorded under $Z+C$. This might be due to the fact that $Z$. mauritiana is managed as a moderate size shrub and severely pruned every year to initiate fresh branches as the fruit is

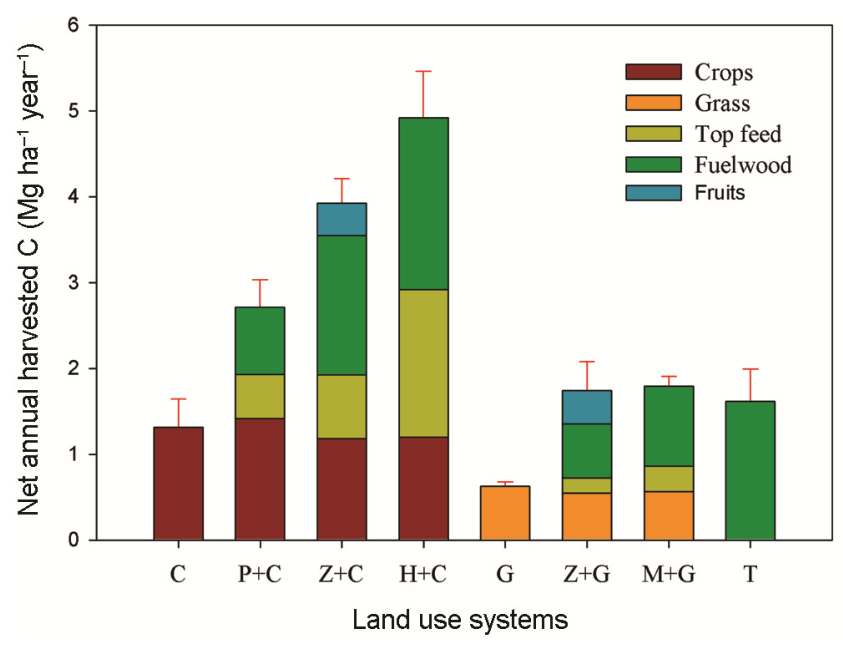

Figure 1. Net annual harvested carbon in different land use systems (average of five years) 


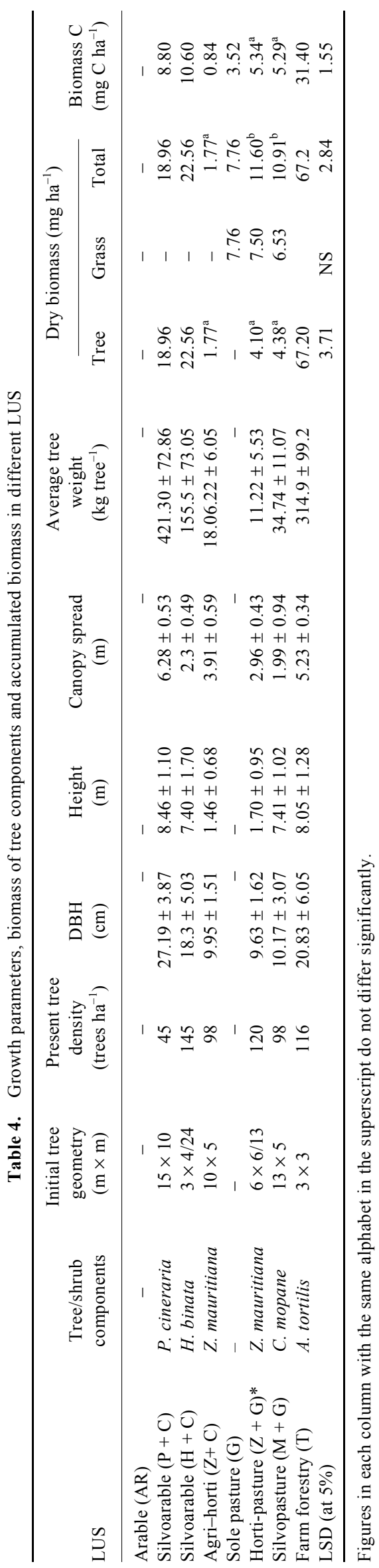


RESEARCH ARTICLES

Table 5. Depthwise distribution of soil organic carbon (SOC) and soil inorganic carbon (SIC) in different LUS

\begin{tabular}{|c|c|c|c|c|c|c|c|c|c|c|}
\hline \multirow[b]{2}{*}{ LUS } & \multicolumn{5}{|c|}{ SOC ( $\mathrm{g} \mathrm{kg}^{-1}$ soil $)$} & \multicolumn{5}{|c|}{ SIC (g kg-1 soil) } \\
\hline & $0-15$ & $15-30$ & $30-45$ & $45-60$ & $60-100$ & $0-15$ & $15-30$ & $30-45$ & $45-60$ & $60-100$ \\
\hline Silvoarable $(\mathrm{P}+\mathrm{C})$ & $3.29^{\mathrm{b}}$ & $2.12^{\mathrm{a}}$ & $1.75^{\mathrm{bc}}$ & $1.53^{\mathrm{ba}}$ & $0.94^{\mathrm{b}}$ & $3.72^{\mathrm{e}}$ & $2.48^{\mathrm{ab}}$ & $2.57^{\mathrm{a}}$ & $3.90^{\mathrm{c}}$ & $3.85^{\mathrm{a}}$ \\
\hline Silvoarable $(\mathrm{H}+\mathrm{C})$ & $3.41^{\mathrm{b}}$ & $2.56^{\mathrm{bc}}$ & $1.62^{\mathrm{ab}}$ & $1.57^{\mathrm{b}}$ & $0.97^{\mathrm{b}}$ & $2.81^{\mathrm{bcd}}$ & $2.76^{\mathrm{abc}}$ & $2.99^{\mathrm{ab}}$ & $4.29^{\mathrm{cd}}$ & $4.02^{\mathrm{ab}}$ \\
\hline Agri-horti $(Z+C)$ & $3.45^{\mathrm{b}}$ & $2.70^{\mathrm{c}}$ & $1.96^{\mathrm{c}}$ & $1.76^{\mathrm{b}}$ & $0.97^{\mathrm{b}}$ & $3.17^{\text {cde }}$ & $3.25^{\mathrm{c}}$ & $3.62^{\mathrm{c}}$ & $3.84^{\mathrm{c}}$ & $3.94^{\mathrm{ab}}$ \\
\hline Horti-pasture $(Z+G)$ & $2.87^{\mathrm{a}}$ & $2.78^{\mathrm{c}}$ & $1.59^{\mathrm{ab}}$ & $1.48^{\mathrm{a}}$ & $0.95^{\mathrm{b}}$ & $3.31^{\mathrm{de}}$ & $3.07^{\mathrm{bc}}$ & $3.53^{\mathrm{bc}}$ & $3.75^{\mathrm{bc}}$ & $3.89^{\mathrm{ab}}$ \\
\hline Silvopasture $(\mathrm{M}+\mathrm{G})$ & $2.79^{\mathrm{a}}$ & $2.45^{\mathrm{b}}$ & $1.42^{\mathrm{a}}$ & $1.31^{\mathrm{a}}$ & $0.91^{\mathrm{b}}$ & $2.59^{\mathrm{abc}}$ & $2.41^{\mathrm{a}}$ & $3.10^{\mathrm{abc}}$ & $3.23^{\mathrm{ab}}$ & $3.75^{\mathrm{a}}$ \\
\hline Farm forestry $(\mathrm{T})$ & 4.20 & 3.41 & 2.30 & 2.08 & $0.99^{\mathrm{b}}$ & 7.01 & 6.50 & 5.58 & 6.08 & $4.45^{\mathrm{b}}$ \\
\hline Mean & 3.18 & 2.56 & 1.72 & 1.58 & 0.95 & 3.38 & 3.16 & 3.46 & 4.08 & 3.97 \\
\hline \multicolumn{11}{|l|}{ LSD (at 5\%) } \\
\hline Depth (D) & 0.07 & & & & & 0.18 & & & & \\
\hline Depth at the same levels of LUS & 0.21 & & & & & 0.52 & & & & \\
\hline
\end{tabular}

Figures in each column with the same alphabet in the superscript do not differ significantly.

borne on them only. Higher $\mathrm{C}$ accumulation in hortipasture system $(\mathrm{Z}+\mathrm{G})$ having the same tree species was due to the fact that, initially for 11 years it was managed as a comparatively tall-statured and less-pruned $Z$. rotundifolia + grass system, and then rejuvenated by beheading and grafting short-statured Z. mauritiana for economic consideration (mainly valued for fruits). The harvested mass of $Z$. rotundifolia (3.6 tonnes $\mathrm{ha}^{-1}$ ) was also accounted for while calculating the biomass $C$ stock of this system. In grass-based systems, $\mathrm{C}$ accumulated in grass sods (2.96-3.41 $\mathrm{Mg} \mathrm{C} \mathrm{ha}^{-1}$ ) was also considered, which was fairly close to the value of $3.64 \mathrm{Mg} \mathrm{C} \mathrm{ha}^{-1}$ reported in $C$. ciliaris pastures in the arid Kachchh region of Gujarat $^{18}$.

\section{Soil C}

The vertical distribution of $\mathrm{C}$ in the soil profile revealed that the mean SOC concentration was highest in the surface layer (3.18 $\mathrm{g} \mathrm{kg}^{-1}$ soil; Table 5). The zone of accumulation of SOC (depth up to which SOC concentration was significantly higher over arable system) varied in different LUS, i.e. $0-60 \mathrm{~cm}$ in $\mathrm{T}, 0-45 \mathrm{~cm}$ in $\mathrm{Z}+\mathrm{C}, 0$ $30 \mathrm{~cm}$ in $\mathrm{H}+\mathrm{C}$ and only in the surface layer $(0-15 \mathrm{~cm})$ in $\mathrm{G}$. The reason for the variation in quantum and distribution of SOC in different LUS could be attributed to differences in quantity and quality of foliage/litter accumulated on the surface, their decomposition pattern and depth of root penetration ${ }^{15,30}$. Foliage production is a function of genetic potential of the species, density and other management practices. Only a part of this foliage is available as litterfall, because a major portion of it is consumed as forage by animals in the farming systems of the arid regions. There is differential preference of species by the animals as their feed. Species like $P$. cineraria, Ziziphus sp., H. binata and C. ciliaris are most preferred and thus less litterfall availability, whereas, A. tortilis is less preferred for feed. Although the foliage of Z. mauritiana is palatable, it has high litterfall availability in $\mathrm{Z}+\mathrm{C}$ system due to the fact that animals are not allowed to graze in this system till fruit-picking is over. This species has a typical character to shed its leaves quickly after fruit maturity, providing less opportunity to the animals to consume the foliage. Similar improvement in SOC in $Z$. mauritiana-based system was reported in Bikaner, Rajasthan ${ }^{16,17}$. The SOC built up is inversely proportional to the decomposition rate of leaf litter. The time required for $99 \%$ decay of litter was 588, 390 and 287 days for $C$. mopane, $A$. tortilis and $P$. cineraria respectively ${ }^{15,31}$. Soil operations like tillage accelerate the oxidation of organic matter ${ }^{32-34}$. The intensity of tillage was highest in cropbased systems followed by pasture and no tillage in farm forestry. In pasture-based systems, majority of roots of $C$. ciliaris were confined to the upper $20 \mathrm{~cm}$ soil layer and had higher soil binding, confirming higher SOC in the surface layer ${ }^{35}$. Thus, differential management practices of LUS affect SOC concentration.

Earlier findings revealed that there was net depletion of SOC in the arid regions mainly due to cultivation of annual cropping. Singh et al. ${ }^{10}$ reported that 27 years of pearl millet cropping in different soil types depleted SOC stock in the order Typic Torrisamments $(19.7 \%)>$ Lithic Torripsamments $>$ Typic Haplocambids $(0.9 \%)$. The results of the present study indicate that this depletion of SOC can be reversed by adopting agroforestry systems (Table 6). The SOC build-up reported here under arid environment is far less than that reported from other ecological settings in India ${ }^{22}$. However, assessment of arid and semi-arid regions for their $\mathrm{C}$ sequestration potential would be underestimated if changes in SIC were not considered. In fact, SIC, rather than SOC, is the dominant form of carbon in arid and semiarid areas ${ }^{21,22}$. The SIC stock in arid regions is approximately $2-10$ times higher 
Table 6. Soil C stock, total C stock (biomass + soil) and sequestration rate in different LUS over 19 years

\begin{tabular}{|c|c|c|c|c|c|c|}
\hline \multirow[b]{2}{*}{ LUS } & \multicolumn{3}{|c|}{ Soil C stock $\left(\mathrm{Mg} \mathrm{C} \mathrm{ha}^{-1}\right)$} & \multirow{2}{*}{$\begin{array}{c}\text { Total C stock } \\
\text { (biomass + soil; } \mathrm{Mg} \mathrm{C} \mathrm{ha}^{-1} \text { ) }\end{array}$} & \multicolumn{2}{|c|}{$\mathrm{C}$ sequestration } \\
\hline & SOC & $\mathrm{SIC}$ & Total & & Total $\left(\mathrm{Mg} \mathrm{C} \mathrm{ha}{ }^{-1}\right)$ & Rate $\left(\mathrm{Mg} \mathrm{C} \mathrm{ha}{ }^{-1}\right.$ year $\left.^{-1}\right)$ \\
\hline Arable (AR) & $9.27^{\mathrm{a}}$ & $19.03^{\mathrm{a}}$ & $28.30^{\mathrm{a}}$ & 28.30 & -1.00 & -0.05 \\
\hline Silvoarable $(P+C)$ & $10.33^{\mathrm{bc}}$ & $21.14^{\mathrm{b}}$ & $31.47^{\mathrm{bc}}$ & $40.27^{\mathrm{d}}$ & 10.97 & 0.58 \\
\hline Silvoarable $(\mathrm{H}+\mathrm{C})$ & $10.82^{\mathrm{c}}$ & $21.37^{\mathrm{b}}$ & $32.19^{\mathrm{cd}}$ & $42.79^{\mathrm{d}}$ & 13.29 & 0.70 \\
\hline Agri-horti $(Z+C)$ & 11.49 & $22.42^{\mathrm{c}}$ & $33.91^{\mathrm{d}}$ & $34.75^{\mathrm{ab}}$ & 5.45 & 0.29 \\
\hline Horti-pasture $(Z+G)$ & $10.02^{\mathrm{b}}$ & $22.1^{\mathrm{cd}}$ & $32.48^{\mathrm{cd}}$ & $37.81^{\mathrm{bc}}$ & 8.31 & 0.44 \\
\hline Silvopasture $(M+G)$ & $9.78^{\mathrm{ab}}$ & $20.96^{\mathrm{abc}}$ & $30.98^{\mathrm{bc}}$ & $36.27^{\mathrm{bc}}$ & 5.41 & 0.28 \\
\hline Farm forestry $(\mathrm{T})$ & 13.50 & 34.10 & 47.60 & 79.00 & 49.80 & 2.62 \\
\hline LSD (at 5\%) & 0.66 & 1.78 & 2.05 & 2.97 & - & - \\
\hline
\end{tabular}

Figures in each column with the same alphabet in the superscript do not differ significantly.
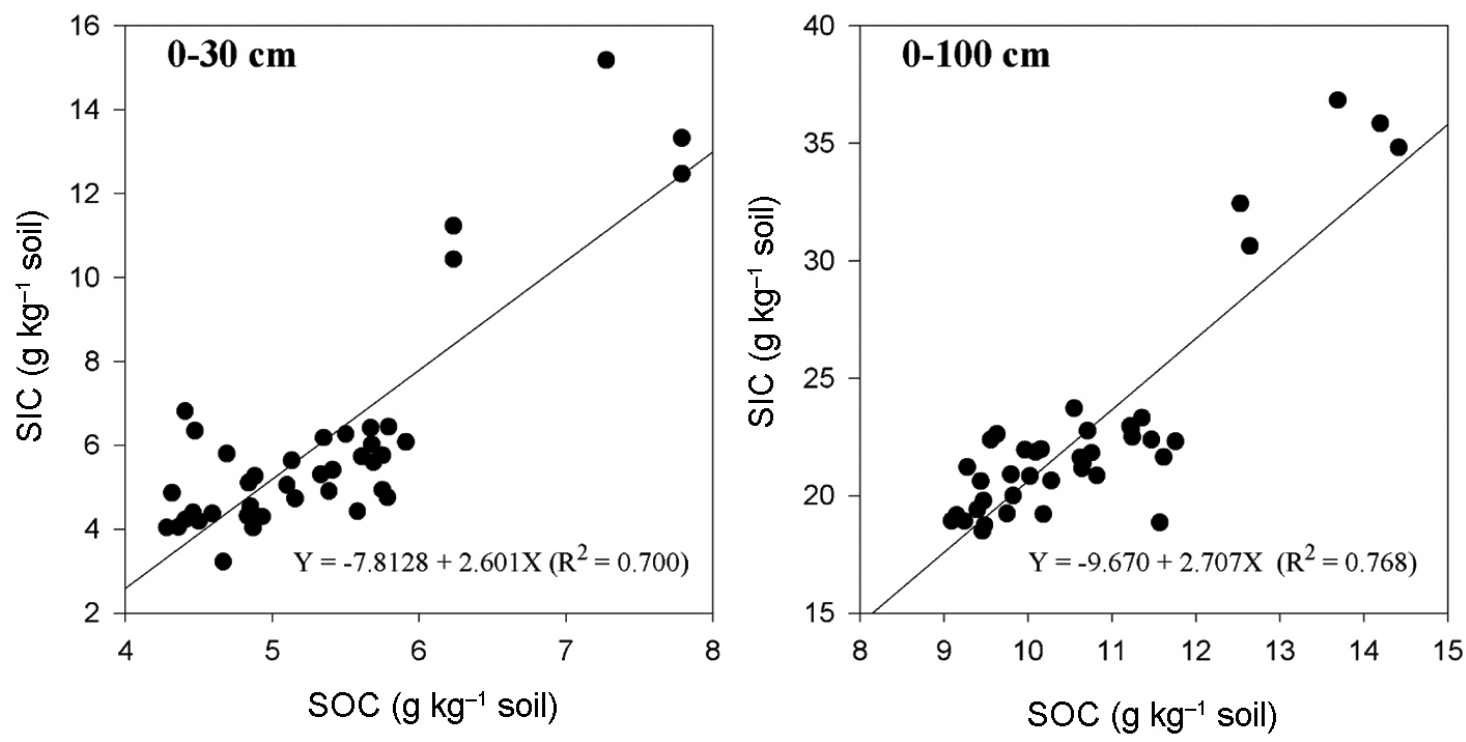

Figure 2. Relationship between soil organic carbon (SOC) and soil inorganic carbon (SIC) in $0-30 \mathrm{~cm}$ and $0-100 \mathrm{~cm}$ soil depth

than SIC stock reported globally ${ }^{20,36,37}$. In the present study, the SIC concentration was almost equal to SOC in the top $30 \mathrm{~cm}$ layer, double in the $30-60 \mathrm{~cm}$ layer and three times or so in the $60-100 \mathrm{~cm}$ layer. The proportion of SIC in additional soil $\mathrm{C}$ stock $(0-100 \mathrm{~cm})$ in different LUS, i.e. increment over arable system was $50-78 \%$ (Table 6). Three-fourth of it was concentrated in the $0-30 \mathrm{~cm}$ layer. There appears to be a synergy in SOC and SIC sequestration as evident from the positive linear relationship $(P<0.01)$ between them (Figure 2). Similar trend was reported in some studies from arid and semi-arid regions of Northwest China ${ }^{38,39}$. Since most of the arid soils are calcareous, $\mathrm{CO}_{2}$ reacts with water and calcium $\left(\mathrm{Ca}^{2+}\right)$ in the upper horizons of the soil and forms secondary carbonates that lock the $\mathrm{C}$ more firmly than in $\mathrm{SOC}^{40}$. Higher decomposition of organic matter and oxidation of SOC under hot arid environment, and root respiration of tree components elevate $\mathrm{CO}_{2}$ concentration in the soil, thus resulting in higher SIC build-up ${ }^{20,41}$.
As total soil C stock is the summation of SOC and SIC, it follows a similar trend being significantly higher in tree-based systems over arable (Table 6). Highest improvement of $18.40 \mathrm{Mg} \mathrm{Cha}^{-1}$ over arable was recorded under farm forestry followed by $\mathrm{Z}+\mathrm{C}$ (4.61 Mg C $\left.\mathrm{ha}^{-1}\right)$. The increase in other systems varied between 2.97 and $2.17 \mathrm{Mg} \mathrm{C}^{-1}$ in the order $\mathrm{Z}+\mathrm{G}>\mathrm{H}+\mathrm{C}>\mathrm{P}+\mathrm{C}$.

\section{Total C stock (soil + biomass) and sequestration rate}

The total $\mathrm{C}$ stock under different LUS varied from $79 \mathrm{Mg} \mathrm{Cha}^{-1}(\mathrm{~T})$ to $34.50 \mathrm{Mg} \mathrm{C} \mathrm{ha}^{-1}(\mathrm{G})$ compared to 28.30 $\mathrm{Mg} \mathrm{C} \mathrm{ha}^{-1}$ in arable (Table 6). Maximum $\mathrm{C}$ sequestered (over initial $\mathrm{C}$ stock) was under $A$. tortilis-based farm forestry (49.80 $\mathrm{Mg} \mathrm{C} \mathrm{ha}^{-1}$ ), both in soil and biomass (a) $2.62 \mathrm{Mg} \mathrm{C} \mathrm{ha}^{-1}$ year $^{-1}$. The silvoarable systems $(\mathrm{H}+\mathrm{C}$ and $\mathrm{P}+\mathrm{C}$ ) sequestered 10.97-13.62 $\mathrm{Mg} \mathrm{C} \mathrm{ha}^{-1}$ followed 
by horti-pasture system $\left(8.31 \mathrm{MgC} \mathrm{ha}^{-1}\right)$. All other systems sequestered between 0.28 and $0.70 \mathrm{Mg} \mathrm{C}^{-1}$ year $^{-1}$. The major share of this $\mathrm{C}$ sequestered was in biomass, i.e. $80.2 \%, 79.7 \%, 66.4 \%, 64.4 \%, 97.8 \%$ and $63 \%$ in $\mathrm{P}+\mathrm{C}, \mathrm{H}+\mathrm{C}, \mathrm{G}, \mathrm{Z}+\mathrm{G}, \mathrm{M}+\mathrm{G}$ and $\mathrm{T}$ respectively. However, $\mathrm{C}$ sequestration in soil cannot be undermined because at least $20 \%$ of the total $\mathrm{C}$ sequestered was contributed by soil $\mathrm{C}$. The $\mathrm{C}$ sequestration rates estimated in this study were on the lower side compared to the carbon sequestration potential of agroforestry reported from other regions of India $\left(0.25-19.14 \mathrm{Mg} \mathrm{C}^{-1} \mathrm{year}^{-1}\right)^{6}$ and the world, i.e. $0.29-15.21 \mathrm{Mg} \mathrm{Cha}^{-1}$ year $^{-1}$ in above ground, and 30-300 $\mathrm{Mg} \mathrm{C} \mathrm{ha}^{-1}$ up to a depth of $1 \mathrm{~m}$ in the soil (age varied from 4 to 35 years) ${ }^{42}$. However, this subtle change when realized over a large area in the arid region can alter the regional carbon budget and make this region a major $\mathrm{C}$ sink.

\section{Conclusion}

This study indicated the $\mathrm{C}$ sequestration potential of arid regions by adopting agroforestry systems. We conclude that trees in different LUS significantly increased $\mathrm{CO}_{2}$ assimilation, which is partly harvested as economic product and partly accumulated as standing biomass and in soil. It was found that $50-75 \%$ improvement in total soil $\mathrm{C}$ stock was due to change in SIC stock, thus underlying the importance of SIC while estimating C sequestration potential in the arid regions. More studies are needed to understand the underlying mechanism. Maximum $\mathrm{C}$ sequestration occurred in block plantation of $A$. tortilis as farm forestry, followed by silvoarable and horti-pasture systems. Since different LUS have their own niches, their extent of adoption and preference of one over another would depend on other factors like economic considerations, farmers' needs, available resources, etc.

1. Lal, R. and Bruce, J. P., The potential of world cropland soil to sequester carbon and mitigate greenhouse effect. Environ. Sci. Policy, 1999, 2, 177-185.

2. Lal, R., Hassan, H. M. and Dumanski, J. M., Desertification control to sequester $\mathrm{C}$ and mitigate the greenhouse effect. In Carbon Sequestration in Soils: Science, Monitoring and Beyond (eds Rosenberg, R. J. et al.), Battelle Press, Columbus, Ohio, USA, 1999, pp. 83-107.

3. Lal, R., Carbon sequestration in dryland ecosystems. Environ. Manage., 2004, 33(4), 528-544.

4. Lal, R., Carbon sequestration in soils of Central Asia. Land Degrad. Dev., 2004, 15, 563-572.

5. Chavan, S. B, Keerthika, A., Dhyani, S. K., Handa, A. K., Ram Newaj and Rajarajan K., National Agroforestry Policy in India: a low hanging fruit. Curr. Sci., 2015, 108(10), 1826-1834.

6. Dhyani, S. K., Asha Ram and Inder Dev, Potential of agroforestry in carbon sequestration in India. Indian J. Agric. Sci., 2016, 86(9), 1103-1112.

7. Sathaye, J. A. and Ravindranath, N. H., Climate change mitigation in the energy and the forestry sectors of developing countries. Annu. Rev. Energ. Environ., 1998, 23, 387-437.
8. Lal, R., Potential of desertification control to sequester carbon and mitigate the greenhouse effect. Climate Change, 2001, 51, 335372.

9. Lal, R., Carbon sequestration in dryland ecosystems of West Asia and North Africa. Land Degrad. Dev., 2002, 13, 45-59.

10. Singh, S. K., Mahesh Kumar, Sharma, B. K. and Tarafdar, J. C., Depletion of organic carbon, phosphorus and potassium stock under a pearl millet based cropping system in the arid region of India. Arid Land Res. Manage., 2007, 21, 119-131.

11. Tewari, J. C., Ram, M. and Roy, M. M., Livelihood improvements and climate change adaptations through agroforestry in hot arid environments. In Agroforestry Systems in India: Livelihood \& Ecosystem Services (eds Dagar et al.), Advances in Agroforest., Springer, India, 2014; doi:10.1007/978-81-322-1662-9 6.

12. Tanwar, S. P. S., Akath Singh, Bhati, T. K., Patidar, M., Mathur, B. K., Praveen Kumar and Yadav, O. P., Rainfed integrated farming system for arid zone of India: resilience unmatched. Indian J. Agron., 2018, 63(4), 403-414.

13. Rathore, V. S., Tanwar, S. P. S., Praveen Kumar and Yadav, O. P., Integrated farming system: key to sustainability in arid and semiarid regions. Indian J. Agric. Sci., 2019, 89(2), 181-192.

14. Tanwar, S. P. S., Akath Singh, Praveen Kumar, Mathur, B. K. and Patidar, M., Rainfed integrated farming systems for arid zone agriculture: diversification for resilience. Indian Fmg., 2018, 68(09), 29-32.

15. Yadav, B. S., Yadav, B. L. and Chhipa, B. R., Litter dynamics and soil properties under different tree species in a semi-arid region of Rajasthan, India. Agrofor. Syst., 2008, 73, 1-12.

16. Awasthi, O. P. and Singh, I. S., Effect of ber and pomegranate plantation on soil nutrient status of typic torripsamments. Indian J. Hortic., 2010, 67, 138-142.

17. Singh, I. S., Awasthi, O. P., Singh, R. S., More, T. A. and Meena, S. R., Changes in soil properties under tree species. Indian J. Agric. Sci., 2012, 82(2), 146-151.

18. Mangalassery, S., Devi Dayal, Meena, S. L. and Bhagirath Ram, Carbon sequestration in agroforestry and pasture systems in arid northwestern India. Curr. Sci., 2014, 107(8), 1290-1293.

19. Gupta, D. K., Bhatt, R. K., Keerthika, A., Noor Mohammed, M. B., Shukla, A. K. and Jangid, B. L., Carbon sequestration potential of Hardwickia binata Roxb. Based agroforestry in hot semi-arid environment of India: an assessment of tree density impact. Curr. Sci., 2019, 116(1), 112-116.

20. Sahrawat, K. L., Importance of inorganic carbon in sequestering carbon in soils of dry region. Curr. Sci., 2003, 84, 864-865.

21. Mielnick, P., Dugas, W.A., Mitchell, K. and Havstad, K., Long-term measurements of $\mathrm{CO}_{2}$ flux and evapotranspiration in a Chihuahuan desert grassland. J. Arid Environ., 2005, 60, 423436.

22. Mi, N., Wang, S. Q., Liu, J. Y., Yu, G. R., Zhang, W. J. and Jobbágy, E., Soil inorganic carbon storage pattern in China. Global. Change Biol., 2008, 14, 2380-2387.

23. Jain, R. C., Tripathi, S. P., Kumar, V. S. K. and Kumar, S., Volume tables for Acacia tortilis plantations based on data collected from KJD Abadi plantation of Khajuwala range, IGNP area, Rajasthan. Indian For., 1996, 122, 316-322.

24. Chave, J. et al., Tree allometry and improved estimation of carbon stocks and balance. Oecologia, 2005, 145, 87-99.

25. Illic, J., Boland, D., McDonald, M., Downes, G. and Blackmore, P., Wood density. Phase 1 - state of knowledge. National carbon accounting system technical report no. 18, Australian Greenhouse Office, Canberra, Australia, 2000.

26. Andrade, H. J., Brook, R. and Ibrahim, M., Growth, production and carbon sequestration of silvopastoral systems with native timber species in the dry lowlands of Costa Rica. Plant Soil, 2008, 308, 11-22.

27. Walkley, A. and Black, I. A., An examination of Degtjareff method for determining soil organic matter and a proposed 
modification of the chromic acid titration method. Soil Sci., 1934 37, 29-37.

28. Muthana, K. D. and Arora, G. D., Acacia tortilis (Forsk) - a promising fast growing tree for Indian arid zone. Central Arid Zone Research Institute Tech. Bull. No. 5, 1979, 1-20.

29. Patel, K. N., Shakhela, R. R. and Jat, J. R., Growth, biomass production and $\mathrm{CO}_{2}$ sequestration of some important multipurpose trees under rainfed condition. Int. J. Curr. Microbiol. Appl. Sci., 2017, 6(10), 1943-1950.

30. Jobbagy, E. G. and Jackson, R. B., The vertical distribution of soil organic carbon in relation to climate and vegetation. Ecol. Appl., 2000, 10, 423-436.

31. Soni, M. L., Yadava, N. D. and Bhardwaj, S., Dynamics of leaf litter decomposition of four tree species of arid western Rajasthan under varying soil moisture regimes. Int. J. Trop. Agric., 2016, 34(4), 955-960.

32. Bear, M. H., Cabrera, M. L., Hendrix, P. F. and Coleman, D. C., Aggregate-protected and unprotected organic matter pools in conventional and no-tillage soils. Soil Sci. Soc. Am. J., 1994, 58, 787795.

33. Roscoe, R. and Burman, P., Tillage effects on soil organic matter in the density fractions of a Cerrado Oxisol. Soil Tillage Res., 2003, 70, 107-119.

34. Kladivko, E. J., Tillage systems and soil ecology. Soil Tillage Res., 2001, 61, 61-76.

35. Soni, M. L., Beniwal, R. K., Talvar, H., Yadava, N. D., Sing, J. P. and Sunil Kumar, Root distribution pattern of sewan (Lasiurus sindicus) and buffel grass (Cenchrus ciliaris) of arid ecosystem of western Rajasthan in relation to their soil binding capacity. Indian J. Agric. Sci., 2006, 76(12), 716-720.
36. Tan, W. F. et al., Soil inorganic carbon stock under different soil types and land uses on the Loess Plateau region of China. Catena, 2014, 121, 22-30.

37. Schlesinger, W. H., Carbon storage in the Caliche of arid soils: a case study from Arizona. Soil Sci., 1982, 133, 247-255.

38. Wang, X. J., Wang, J. P., Minggang, Xu, Zhang, W., Fan, T. and Zhang, J., Carbon accumulation in arid croplands of northwest China: pedogenic carbonate exceeding organic carbon. Sci. Rep., 2015, 5, 11439.

39. Li, Z. P. et al., Assessment of soil organic and carbonate carbon storage in China. Geoderma, 2007, 138, 119-126.

40. Lal, R., Residue management, conservation tillage and soil restoration for mitigating greenhouse effect by $\mathrm{CO}_{2}$-enrichment. Soil Tillage Res., 1997, 43, 81-107.

41. Wang J. P., Wang, X. J., Zhang, J. and Zhao, C. Y., Soil organic and inorganic carbon and stable carbon isotopes in the Yanqi basin of northwestern China. Eur. J. Soil Sci., 2015, 66, 95-103.

42. Nair, P. K. R., Nair, V. D., Kumar, B. M. and Showalter, J. M., Carbon sequestration in agroforestry systems. Adv. Agron., 2010, 108, 237-307.

ACKNOWLEDGEMENTS. The contribution of all project associates and the then Directors of ICAR-Central Arid Zone Research Institute, Jodhpur in establishing and maintaining the integrated farming system is gratefully acknowledged. We are thankful to National Initiative on Climate Resilient Agriculture for financial support.

Received 15 April 2019; revised accepted 13 September 2019

doi: $10.18520 / \mathrm{cs} / \mathrm{v} 117 / \mathrm{i} 12 / 2014-2022$ 